\title{
UPAYA MENGEMBANGKAN MOTORIK HALUS ANAK USIA DINI MELALUI KEGIATAN MENGGUNTING
}

\author{
Yan Yan Nurjani ${ }^{1)}$, Endah Jubaedah ${ }^{2)}$, Sri Nurjayati ${ }^{3)}$, dan Siti Aliyah ${ }^{4)}$ \\ ${ }^{1}$ Sekolah Tinggi Agama Islam Al-Musaddadiyah Garut \\ ${ }^{2}$ Sekolah Tinggi Agama Islam Al-Musaddadiyah Garut \\ ${ }^{3}$ Sekolah Tinggi Agama Islam Al-Musaddadiyah Garut \\ ${ }^{4}$ Sekolah Tinggi Agama Islam Al-Musaddadiyah Garut \\ email : ${ }^{1}$ yan.yan@ stai-musaddadiyah.ac.id
}

\begin{abstract}
ABSTRAK
Penelitian ini bertujuan untuk mengembangkan motorik halus melalui kegiatan menggunting pada anak usia dini di kelompok B TK YBA'45 Kecamatan Tarogong Kidul Kabupaten Garut. Penelitian ini merupakan penelitian tindakan kelas yang dilaksanakan dalam 2 siklus. Subjek penelitian ini adalah anak-anak kelompok B TK YBA'45 Tarogong Kidul yang berjumlah 15 anak. Penelitian dilaksanakan pada semester II pada bulan April sampai Mei tahun ajaran 2017/2018. Teknik pengumpulan data yang digunakan dalam penelitian ini adalah observasi. Instrumen pengumpulan data menggunakan lembar observasi. Analisis data yang digunakan adalah deskriptif kualitatif. Hasil penelitian pengembangan motorik halus Pra Tindakan menunjukan kriteria kurang baik dengan nilai rata-rata pengembangan motorik halus sebesar $46.65 \%$. Hasil penelitian pada Siklus I menunjukan kriteria cukup dengan nilai rata-rata pengembangan motorik halus sebesar $63.3 \%$. Setelah dilakukan tindakan pada siklus I telah menunjukan keberhasil dalam mengembangkan motorik halus tetapi belum mencapai indikator keberhasilan sehingga diperlukan siklus selanjutnya. Hasil Siklus II pencapaian kriteria baik dengan nilai ratarata pengembangan motorik halus sebesar $87.8 \%$. Berdasarkan hasil penelitian dan uraian tersebut dapat disimpulkan bahwa melalui kegiatan menggunting dapat mengembangkan motorik halus pada anak kelompok B semester II di TK YBA’45 Tarogong Kidul sebesar 24.5\%.
\end{abstract}

Kata kunci: Kegiatan Menggunting, Pengembangan Motorik Halus

\begin{abstract}
This research aims to develop fine motor through cutting activity in early childhood in group B TK YBA'45 Tarogong Kidul District Garut Regency. This research is a classroom action research conducted in 2 cycles. The subjects of this study were children of B TK YBA'45 Tarogong Kidul group with 15 children. The study was conducted in the second half of April to May 2016/2017 academic year. Data collection technique used in this research is observation. The data collection instrument uses an observation sheet. Data analysis used is descriptive qualitative. Result of research of fine motor development of Pre Action show bad criterion with average value of fine motor development equal to $46.65 \%$. The results of research in Cycle I showed sufficient criteria with the average value of fine motor development
\end{abstract}


Journal of S.P.O.R.T, Vol. 3, No.2, Desember 2019

ISSN 2620-7699

Sport, Physical Education, Organization, Recreation, Training

of 63.3\%. After the action in cycle I has shown success in developing fine motor but not yet achieved the success indicator so that the next cycle is needed. Results Cycle II achievement of good criteria with the average value of fine motor development of $87.8 \%$. Based on the results of the study and the description can be concluded that through cutting activities can develop fine motor in children group B semester II in TK YBA'45 Tarogong Kidul $24.5 \%$.

Keywords: Cutting Activities, Development of fine motor 


\section{PENDAHULUAN}

Pendidikan anak usia dini adalah suatu upaya pembinaan yang ditujukan kepada anak usia 0-6 tahun. Dalam undang-undang nomor 20 tahun 2003 tentang Sistem Pendidikan Nasional, pasal 1 angka 14, (2016:4) menyatakan bahwa pendidikan anak usia dini (PAUD) adalah suatu upaya pembinaan yang ditujukan kepada anak sejak lahir sampai dengan usia enam tahun yang dilakukan melalui pemberian rangsangan pendidikan untuk membantu pertumbuhan dan perkembangan jasmani dan rohani agar anak memiliki kesiapan dalam memasuki pendidikan lebih lanjut.

Dalam hal ini anak usia dini berada dalam masa emas perkembangan, terutama motorik kasar, anak menyenangi kegiatan fisik mulai mengembangkan keterampilan baru dan memperbaiki keterampilan sebelumnya. Berbeda dengan motorik halus yang berkembang lebih lamban, tetapi tetap dibantu dengan menyediakan kesempatan seluasnya-luasnya, begitupun peralatan dan bahan yang sesuai dan dukungan yang terus menerus diberikan kepada anak, adapun masalah atau kesulitan yang dihadapi anak dalam pengembangan motorik halus yaitu belum bisa menggunting dengan ketepatan, ketelitian, juga kerapihan yang sangat baik.

Aktivitas pengembangan motorik halus anak taman kanak-kanak sangat bermanfaat untuk melatih keterampilan koordinasi motorik anak diantaranya koordinasi antara tangan dan mata yang dapat dikembangkan melalui kegiatan bermain. Adapun tujuan dari pengembangan motorik halus yaitu: mampu memfungsikan otot-otot kecil, seperti gerakan jari tangan, mampu mengkoordinasi kecepatan tangan dan mata. Manfaat lain dari pengembangan motorik halus yaitu untuk mendukung aspek pengembangan lainnya, seperti kognitif, bahasa, dan sosial. Karena setiap aspek perkembangan tidak terpisah antara satu sama lain (Saputra, 2005).

Adapun faktor-faktor yang dapat mempengaruhi perkembangan gerak motorik terutama motorik halus, antara lain: perkembangan sistem saraf, kemampuan fisik yang memungkinkan untuk bergerak, keinginan anak yang memotivasinya untuk bergerak, lingkungan yang mendukung, aspek psikologis anak, umur, jenis kelamin, genetik, kelainan kromosom (AlMaqassary, 2014).

Beberapa cara yang dilakukan untuk mengembangkan motorik halus anak usia dini diantaranya yaitu: melipat, menggambar dengan krayon, membentuk atau memanipulasi dari tanah liat/ lilin/ adonan, melukis dengan cat air, bermain kolase, menggunting, merangkai benda dengan tali/benang (meronce). Aktivitas pengembangan motorik halus tersebut bertujuan untuk melatih keterampilan koordinasi motorik anak diantaranya koordinasi antara tangan dan mata yang dapat dikembangkan melalui kegiatan bermain (Novikasari, 2014).

Dari beberapa kegiatan yang dapat mengembangkan motorik halus anak usia dini di atas, peneliti lebih tertarik untuk menggunakan kegiatan menggunting sebagai kegiatan yang dapat mengembangkan motorik halus anak, karena dengan kegiatan menggunting anak dapat terlatih untuk menggunakan jari jemarinya untuk mulai menggunting dari tahap awal sampai sulit. Kegiatan menggunting adalah suatu kegiatan yang dilakukan dengan menggunakan gunting. Menggunting juga termasuk teknik dasar untuk membuat aneka bentuk kerajinan tangan, bentuk hiasan dan 
gambar dari bahan kertas dengan memakai bantuan alat pemotong. Selain itu dengan kegiatan menggunting anak dapat menyesuaikan ketebalan media yang digunakan maupun bahan yang digunakan mulai dari tingkat kesulitan yang temudah sampai tahap menggunting akhir dengan berbagai media tersebut. Selain itu dengan media yang digunakan dalam kegiatan menggunting menjadikan pembelajaran lebih bervariasi sehingga diharapkan anak lebih aktif dan menarik minat anak dalam mengikuti pembelajaran.

Permasalahan inilah yang ditemukan oleh penulis dikelompok B Taman Kanak-kanak Yayasan Bhakti Angkatan (YBA) 45. Berdasarkan latar belakang di atas maka tertarik untuk melakukan penelitian "Upaya Mengembangkan Motorik Halus Anak Usia Dini Melalui Kegiatan Menggunting”.

\section{Metodologi penelitian}

Penelitian yang dilakukan merupakan Penelitian Tindakan Kelas (PTK) yang terfokus pada situasi kelas, atau disebut dengan Classroom Action Research. Penelitian tindakan kelas adalah proses penelitian yang sistematis dan terencana melalui tindakan perbaikan pembelajaran yang dilakukan oleh guru kelasnya sendiri. Penelitian tindakan kelas bertujuan untuk memperbaiki kinerja guru sehingga kualitas kegiatan pengembangan menjadi lebih meningkat. Penelitian Tindakan Kelas (PTK) adalah pencermatan dalam bentuk tindakan terhadap kegiatan belajar yang sengaja dimunculkan dan terjadi dalam sebuah kelas secara bersamaan (Suryadi, 2010).

Berdasarkan uraian para ahli diatas, maka dapat disimpulkan bahwa penelitian tindakan kelas merupakan suatu kegiatn ilmiah yang dilakukan oleh guru dikelasnya sendiri dengan jalan merancang, melaksanakan, mengamati, dan mereflesikan tindakan melalui beberapa siklus yang bertujuan untuk memperbaiki atau meningkatkan kualitas/ mutu proses pembelajaran dikelasnya.

\section{Gambar 2.1 Model Penelitian Tindakan Kelas dari Kemmis dan Mc Taggart}

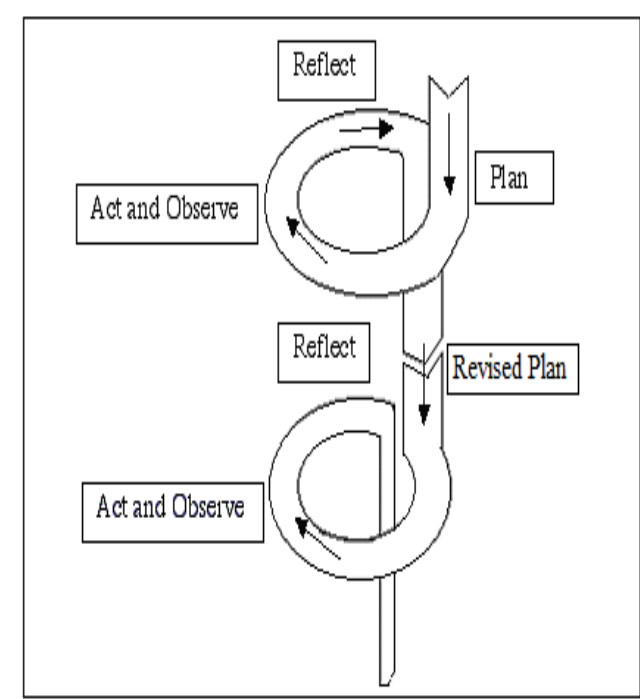

Berdasarkan gambar 2.1 tentang siklus PTK maka dapat dijelaskan bahwa prosedur penelitian tindakan kelas secara sederhana terdiri atas empat tahapan yaitu:
a. Perencanaan
b. Pelaksanaan
c. Pengamatan
d. Refleksi

\section{Landasan Teori}

\subsection{Motorik Halus}

Motorik Merupakan sesuatu
yang berhubungan
dengan
gerakan-gerakan tubuh. Dalam
pengembangan motorik, unsur-
unsur yang menentukan ialah otot,
saraf, dan otak. Ketiga unsur


tersebut

melaksanakan

peranannya secara "interaksi positif", artinya unsur-unsur tersebut saling berkaitan, saling menunjang, saling melengkapi dengan unsur lainnya untuk mencapai kondisi motorik yang lebih sempurna keadaannya. Selain mengandalkan otot, kesempurnaan otak turut menentukan keadaan, karena anak yang pertumbuhan otaknya mengalami gangguan tampak kurang terampil dalam menggerak-gerakan tubuhnya (Sujiono, 2009).

Menurut (Daeng Sari, 2016), motorik halus ialah aktivitas motorik yang melibatkan aktivitas otot-otot kecil atau halus, gerakan ini menuntut koordinasi mata dan tangan serta penegendalian gerak yang baik yang mengharuskan melakukan ketepatan dan ketelitian dalam gerak.

(Yudha M Saputra, 2005) menterjemahkan motorik halus merupakan kemampuan anak dalam beraktivitas dengan menggunakan otot-otot kecil (halus) seperti menulis, meremas, menggenggam, menggambar, menyusun balok, dan memasukan kelereng.

Tujuan dari pengembangan motorik anak usia dini adalah untuk mengembangkan kemampuan motorik anak, melatih anak untuk melakukan gerakan-gerakan kasar dan halus, meningkatkan kemampuan mengelola, mengontrol gerakan tubuh, serta meningkatkan keterampilan tubuh.

\subsection{Kegiatan Menggunting}

Menggunting merupakan kegiatan kreatif yang menarik bagi anak-anak. Menggunting termasuk teknik dasar untuk membuat aneka bentuk kerajinan tangan, bentuk hiasan dan gambar dari bahan kertas dengan memakai bantuan alat pemotong. Sumantri mengemukakan bahwa menggunting adalah memotong berbagai aneka kertas atau bahan-bahan lain dengan mengikuti alur, garis atau bentukbentuk tertentu yang merupakan salah satu kegiatan yang dapat mengembangkan motorik halus anak (Sumantri, 2005).

(Suratno, 2005) menyatakan bahwa kegiatan menggunting membutuhkan keterampilan menggerakkan otot-otot tangan dan jari-jari untuk berkoordinasi dalam menggunting sehingga bisa memotong kertas, kain atau yang lain sesuai yang diinginkan; seperti menggunting yang berpola, menggunting dan melipat untuk membentuk gambar, membentuk pola ataupun yang lain.

(Sumantri, 2005) mengemukakan manfaat kegiatan menggunting untuk mengembangkan keterampilan, melatih koordinasi tangan dan mata, dan konsentrasi yang merupakan persiapan awal atau pengenalan kegiatan menulis. Kegiatan menggunting sangat bermanfaat untuk mengembangkan keterampilan anak dalam menggerakkan otot-otot tangan dan jari-jari anak.

Hubungan Kegiatan Menggunting Dengan Pengembangan Motorik Halus Anak Usia Dini

Anak usia dini berada dalam masa emas perkembangan, terutama motorik kasar, anak menyenangi kegiatan fisik mulai mengembangkan keterampilan baru dan memperbaiki keterampilan sebelumnya. Berbeda dengan motorik halus yang 
berkembang lebih lamban, tetapi tetap dibantu dengan menyediakan kesempatan seluasnya-luasnya, begitupun peralatan dan bahan yang sesuai dan dukungan yang terus menerus di berikan kepada anak, adapun masalah atau kesulitan yang dihadapi anak dalam pengembangan motorik halus yaitu belum bisa menggunting dengan ketepatan, ketelitian, juga kerapihan yang sangat baik (Hildayani, 2009).

Dalam mengembangakan motorik halus anak usia dini diperlukan adanya media yang dapat menunjang agar anak dapat mengembangkan motorik halusnya, salah satunya dengan kegiatan menggunting. Adapun media yang dapat digunakan dalam kegiatan menggunting adalah pensil, spidol, kertas, spon ati, juga gunting sebagai alat pokok dalam kegiatan menggunting.

Dengan kegiatan menggunting, anak dapat terlatih dalam menggunakan otot-otot/ jari, koordinasi otot, mata dan keterampilan tangan, melatih pengamatan, memupuk ketelitian dan kerapian. Kemampuan motorik anak juga didapatkan dengan anak selalu berusaha untuk menggerakkan fisiknya secara terkendali dan terarah sesuai dengan aturan-aturan pada umumnya dalam tata cara menggunting yang dapat mengembangkan motorik halus anak menjadi lebih optimal.

Kemampuan tersebut didapatkan dari olah tangan yang berulang-ulang, sehingga semakin lama anak akan mampu mengendalikan dan megarahkan. Begitupun kegiatan yang dihasilkan dari olah tangan mereka selesai dengan yang dikehendakinya. Dari kebiasaan ini, keterampilan berkarya akan tercapai.

\section{Pembahasan Hasil Penelitian}

\subsection{Hasil Pendahuluan}

Penelitian yang telah dilakukan merupakan penelitian tindakan kelas yang terdiri dari 2 siklus. Setiap siklus terdiri dari perencanaan, pelaksanaan, atau tindakan, observasi, dan refleksi. Hasil yang diperoleh pada siklus ini didapat dari data yang berupa lembar observasi. Dari data lembar observasi tersebut hasilnya digunakan untuk mengetahui peningkatan yang terjadi pada anak. Analisis data dalam penelitian ini terjadi secara interaktif baik sebelum, saat dan sesudah penelitian. Sebelum penelitian dilakukan peneliti, telah melakukan analisis yaitu dalam menentukan rumus masalah yang muncul, kemudian analisis juga dilakukan pada saat pengambilan data kemampuan awal anak. Analisis sebelum penelitian ini bertujuan mengetahui sejauh mana permasalahan dan kemampuan anak sehingga dapat dilakukan tindakan penelitian yang tepat. Berdasarkan hasil observasi tentang pelaksanaan pembelajaran beserta dampak dari stimulasi yang telah diberikan kepada anak, menunjukan bahwa permasalahan yang paling mendominasi yaitu terkait dengan permasalahan pengembangan motorik halus anak.

\subsection{Pembahasan Hasil Validitas}

Berdasarkan data hasil penelitian Pengembangan motorik halus Anak Melalui kegiatan menggunting di Taman Kanak-kanak Yayasan Bhakti Angkatan (YBA)'45 , diperlukan pembahasan guna memperjelas dan memperdalam kajian dalam penelitian ini. Beberapa hal yang perlu diperbaiki yaitu mengenai pembelajaran dan cara memotivasi 
anak agar anak senang melaksanakan pembelajaran.

Pembelajaran ini dapat dilaksanakan dengan pengelolaan kegiatan sambil bermain sehingga kemampuan motorik halus anak melalui kegiatan menggunting menjadi pembelajaran yang menyenangkan bagi anak. Beberapa catatan negatif yang belum teratasi pada Siklus I dilanjutkan pada Siklus II.

Pencapaian hasil yang lebih maksimal, peneliti melakukan pembelajaran pada Siklus II dengan menambahkan bentuk-bentuk kegiatan menggunting yang lainnya dengan menggunakan pola gambar.

Pelaksanaan kegiatan terlebih dahulu dikomunikasikan pada anak dan diutarakan apa yang akan diperoleh dari kegiatan. Berdasarkan tingkat penelitian Siklus I dan Siklus II dapat dijabarkan keberhasilan penggunaan kegiatan menggunting sebagai berikut: Ditinjau dari aktifitas guru, pembelajaran pada Siklus II sudah berjalan dengan baik dan berhasil, Kemampuan motorik halus anak dalam kegiatan menggunting sudah meningkat, Pemberian metode pembelajaran yang menarik bagi anak akan menimbulkan minat anak dalam kegiatan menggunting.

Tabel 4.17 Rekapitulasi Hasil Pra Tindakan, Siklus I dan Siklus II

\begin{tabular}{|c|c|c|c|c|}
\hline \multicolumn{4}{|c|}{ Pengembangan Motorik Halus } & \multirow[b]{3}{*}{ Ket } \\
\hline \multirow[t]{2}{*}{ Kriteria } & & & & \\
\hline & $\begin{array}{c}\text { Tindak } \\
\text { an }\end{array}$ & I & II & \\
\hline Ketepatan & $48.9 \%$ & $66.7 \%$ & $86.7 \%$ & \multirow{2}{*}{$\begin{array}{c}\text { Bai } \\
\text { k }\end{array}$} \\
\hline Kerapian & $44.4 \%$ & $60 \%$ & $84.4 \%$ & \\
\hline
\end{tabular}

Berdasarkan hasil observasi dari sebelum tindakan ke siklus I dan II dapat dilihat perbandingan persentase hasil belajar pada tabel dan histogram di atas. Dari data yang diperoleh, dapat diketahui pencapaian hasil belajar anak dalam menggunting pada anak kelompok B mengalami peningkatan. Histogram tersebut menunjukan peningkatan yang sangat baik dalam pengembangan motorik halus anak dalam proses penelitian tindakan kelas yang dilaksanakan. Pada pertemuan kedua siklus II ini, dapat diketahui bahwa kemampuan rata-rata anak didominasi dengan pengembangan motorik halus anak menggerakkan jari jemari dalam memegang gunting serta dapat menggunting dengan lentur mengikuti pola gambar dengan tepat. Hasil observasi sebelum tindakan dan observasi sesudah tindakan pada siklus I dapat dilihat perbandingan persentase hasil belajar pada tabel dan histogram diatas, terlihat jelas bahwa pengembangan motorik halus anak sebelum tindakan siklus I mengalami peningkatan.

\section{DAFTAR PUSTAKA}

Al-Maqassary, A. (2014). Faktor yang Mempengaruhi Motorik. Jurnal Pendidikan.

Daeng Sari, M. P. (2016). Metode Pengajaran di TK. Jakarta: Depdikbud.

Hildayani, R. (2009). Psikologi

Perkembangan. Jakarta: Universutas Terbuka.

Novikasari, M. (2014). Metode Pengembangan Motorik Anak. Jurnal Pendidikan.

Saputra, Y. (2005). Pembelajaran Kooperatif Untuk Meningkatkan 
Keterampilan Anak Taman KanakKanak. Jakarta: Depdiknas.

Sujiono, B. (2009). Metode Pengembangan Fisik. Jakarta: Universitas Terbuka.

Sumantri. (2005). Model Pengembangan Keterampilan Motorik Anak Usia Dini. Jakarta: Depdiknas.

Suratno. (2005). Pengembangan Kreativitas Anak Usia Dini. Jakarta: Depdiknas.

Suryadi. (2010). Panduan Penelitian

Tindakan Kelas. Jogjakarta: Diva Press.

Yudha M Saputra, R. (2005). Pembelajaran Kooperatif Untuk Meningkatkan Keterampilan Anak TK. Jakarta: Depdiknas. 